\title{
EFFECTS OF THREE KINDS OF SUGAR SYRUPS ON COLONY DEVELOPMENT OF BUMBLE BEE (Bombus terrestris L.)
}

\author{
Fehmi Gurel ${ }^{1}$, Bahar A. Karsli ${ }^{1}$, Ayhan Gosterit ${ }^{2}$ \\ ${ }^{1}$ Department of Animal Science, Faculty of Agriculture, \\ Akdeniz University, 07800, Antalya, Turkey \\ ${ }^{2}$ Department of Animal Science, Faculty of Agriculture, Süleyman \\ Demirel University, Isparta, Turkey \\ e-mail: fgure1@akdeniz.edu.tr
}

Received 06 February 2012; accepted 07 November 2012

\section{$\mathrm{S}$ u m m a r y}

The effects of three kinds of sugar syrups on colony development were studied. Weekly sugar syrup consumption of the Bombus terrestris dalmatinus colonies were investigated. A total of 60 queens were separately placed in standard nest boxes and randomly divided into three groups. We tested high fructose corn syrup (HFCS - fructose 42-45\%, glucose 50-54\%), sucrose syrup (SS - sucrose 99\%), and industrial bee feeding sugar syrup (BFSS - fructose 37-40\%, glucose $27-30 \%$, sucrose $30-36 \%$ ). All queens and colonies were fed with the same fresh pollen and reared under standard laboratory conditions $\left(28 \pm 1^{\circ} \mathrm{C}, 60 \pm 5 \% \mathrm{RH}\right)$. Pollen and sugar syrups (approximately 1:1 water:sugar) were provided ad libitum. Colony development traits, weekly syrup consumption, total syrup consumption, and total pollen consumption of each colony were recorded during periodic observations. The highest egg laying rate, colony production rate and saleable colony production rate $(90,75$, and $50 \%$, respectively) were found in the BFSS treatment. However, no significant difference was found among treatments in terms of examined colony characteristics. Until the colonies were large enough for sale (50-60 workers), the consumption of sugar syrup and pollen per one colony varied from 461 to $546 \mathrm{ml}$ and from 164 to $190 \mathrm{~g}$, respectively.

Keywords: Bumble bee, Bombus terrestris, feeding, sugar syrup, colony development.

\section{INTRODUCTION}

Bumble bees are increasingly used for the pollination of a number of crops, mainly of tomatoes in greenhouses. Currently, five species of bumble bees are reared commercially. The main species is the Eurasian Bombus terrestris L. The current worldwide sales of $B$. terrestris have reached some 900000 colonies per year (Velthuis and Doorn, 2006). This species produces large colonies and adapts quite well to artificial conditions. Although the development of production techniques has been rapid since the start in 1987, there is still the problem of maximizing the quality and profitability of artificially reared colonies in commercial rearing (Hughes, 1996). The colonies of $B$. terrestris show much variation in the number of workers, males, and queens produced (Beekman and van Stratum, 2000). Significant variations are also seen in the colony initiation time, and colony production ratio. These characteristics are important criteria in year round rearing of $B$. terrestris, and are affected by several factors such as the food quality, and climate in the rearing room.

Nectar and pollen are essential food sources for bees. In extensive commercial rearing, bumble bee colonies are normally fed on sucrose or invert sugar solutions (as substitutes for nectar) and fresh pollen collected from pollen traps at honey bee hives. This diet seems to provide adequate nutrition for good colony development (Plowright and Jay, 1966; Ribeiro et al., 1996; Rasmont et al., 2005). 
Previous studies have shown that pollen quality and availability affect the survival, growth, reproduction, and colony development of $B$. terrestris. Ribeiro et al. (1996) found that queens reared on dried-frozen pollen were smaller, had lower biomass, higher mortality, and produced smaller colonies than queens reared on fresh-frozen pollen. Genissel et al. (2002) and Tasei and Aupinel (2008) emphasized that quantitative and qualitative variations of pollen proteins have considerably influence the reproductive success and brood rearing capacity in $B$. terrestris.

In the bumble bee rearing industry, colonies are fed sugar syrups obtained from different plant sources such as Zea mays, Beta vulgaris, and Saccharum spp. because of their low costs, and liquid structures. It is estimated that approximately one million $\mathrm{kg}$ of sugar syrup are used by bumble bee rearing facilities and that another two million $\mathrm{kg}$ of sugar syrup are used annually to feed all of the colonies used in the greenhouses (Velthuis and Doorn, 2006). However, there is hardly any information on which sugar syrups are suitable for bumble bee feeding. Therefore, the main objectives of this work are to compare the effects of three kinds of sugar syrups (sucrose, high fructose corn, and industrial bee feeding sugar syrups) on colony development, and to determine sugar syrup consumption during the colony development of $B$. terrestris.

\section{MATERIALS AND METHODS}

Bombus terrestris dalmatinus queens were obtained from a commercial company and reared under standard laboratory conditions in a climate controlled room $\left(28 \pm 1^{\circ} \mathrm{C}, 60 \pm 5 \% \mathrm{RH}\right)$. To stimulate egg laying, two callow honey bee workers were added to each queen (Gurel and Gosterit, 2008a). These callow workers were changed every week until the first worker emerged. When workers of the first brood emerged, the colonies were transferred to larger plastic boxes. All queens and colonies were fed with the same fresh frozen pollen collected by honey bees. Pollen and sugar syrup were provided ad libitum.

A total of 60 queens were separately placed in standard nest boxes and randomly divided into three groups. We tested high fructose corn syrup (HFCS-42), sucrose syrup (SS), and industrial bee feeding sugar syrup (BFSS). We decided to compare these because they were more readily available. Water was added to give syrups refractometer readings of $50 \%$ (approximately 1:1 water:sugar, w/w) because about a $50 \%$ sugar concentration in syrup proved to be an excellent substitute for nectar (Velthuis and Doorn, 2006). In order to determine the weekly syrup consumption, the syrup that remained in the feeder of each colony was measured every week. The details on the characteristics of sugar syrups used for feeding $B$. terrestris colonies are shown in Table 1.

In this study, a minimum of ten workers was the criterion used to define a colony. Queens that produced fewer than ten workers were not considered to be colony producers (Ribeiro et al., 1996). A bumble bee colony used for crop pollination in greenhouses must contain a healthy queen and at least 50 workers (Velthuis and

Table 1 .

The characteristics of sugar syrups used to feed B.terrestris colonies

\begin{tabular}{||l|c|c|c|c||}
\hline \multicolumn{1}{|c|}{ Syrups } & Plant Source & Sugar Composition (\%) & Brix & pH \\
\hline $\begin{array}{l}\text { High Fructose Corn } \\
\text { Syrup (HFCS-42) }\end{array}$ & $\begin{array}{c}\text { Corn sugar } \\
\text { Zea mays }\end{array}$ & $\begin{array}{c}\text { Fructose 42-45 } \\
\text { Glucose 50-54 }\end{array}$ & 49.42 & 5.56 \\
\hline Sucrose Syrup (SS) & $\begin{array}{c}\text { Sugar beet } \\
\text { Beta vulgaris }\end{array}$ & Sucrose 99 & 49.69 & 5.28 \\
\hline $\begin{array}{l}\text { Industrial Bee Feeding } \\
\text { Sugar Syrup (BFSS) }\end{array}$ & $\begin{array}{c}\text { Sugar beet } \\
\text { Beta vulgaris }\end{array}$ & $\begin{array}{c}\text { Fructose 37-40 } \\
\text { Glucose 27-30 } \\
\text { Sucrose 30-36 }\end{array}$ & 49.12 & 5.25 \\
\hline
\end{tabular}


Doorn, 2006). We considered colonies that produced 50 or more workers as accepted saleable colonies. The feeding trial lasted 11 weeks. During this time period, all the colonies had reached 50-60 workers.

The time of emergence of the first worker, the number of workers in the first brood, egg laying rate, colony production rate, saleable colony production rate and mortality rate for the first month were recorded by periodical observations. Weekly syrup consumption, total syrup consumption, and total pollen consumption of each colony during the experimental period were also measured. Data were analyzed with SPSS 12.0 for Windows. The data presented as means \pm standard errors were interpreted with a KruskalWallis test. When percentages had to be compared a $\chi^{2}$ test was used.

\section{RESULTS}

The time of emergence of the first worker, the number of workers in the first brood, total syrup consumption, total pollen consumption, and the total number of workers produced by each colony were not statistically different among the three feeding groups (Kruskal-Wallis test $\mathrm{P}=0.251, \quad \mathrm{P}=0.120, \quad \mathrm{P}=0.134, \quad \mathrm{P}=0.314$, $\mathrm{P}=0.101$, respectively). At the end of the 11 weeks, average colony size was $58.66 \pm 2.17$ workers in the HFCS group, followed by the SS $(55.14 \pm 1.32)$, and BFSS (53.30 \pm 1.23$)$ groups. The highest

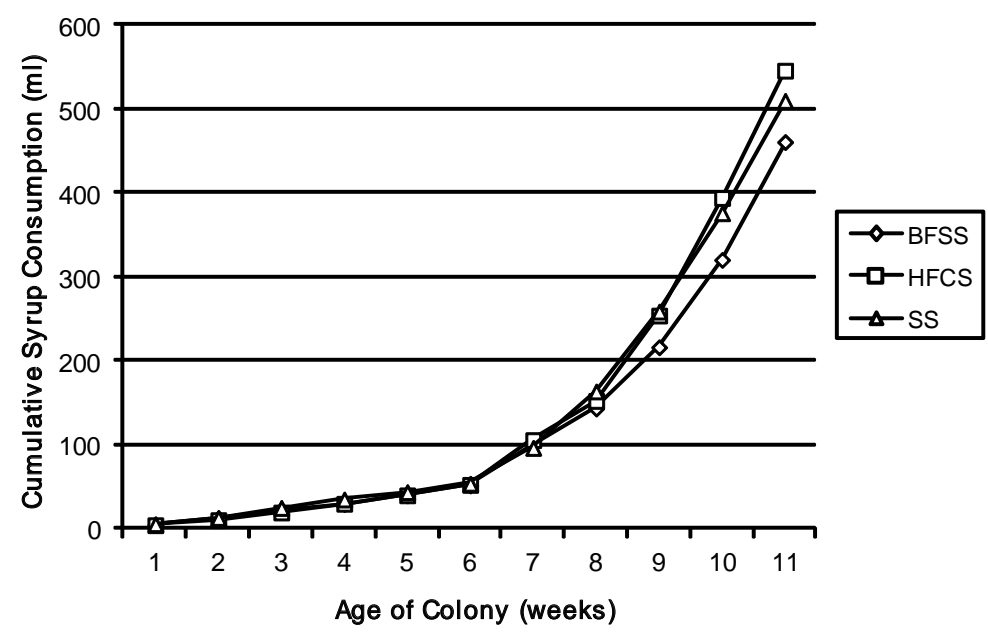

Fig. 1. Average weekly cumulative syrup consumptions during the experimental period.

Table 2.

Colony characteristics depending on the feeding regimes

\begin{tabular}{||l|c|c|c||}
\hline \multicolumn{1}{|c|}{ Colony characteristics } & \multicolumn{3}{c|}{ Syrups } \\
\cline { 2 - 4 } & HFCS-42 ( $\mathbf{n = 6})$ & SS ( $\mathbf{n = 7})$ & BFSS ( $=10)$ \\
\hline First worker emergence (days) & $38.83 \pm 1.01$ & $40.57 \pm 0.75$ & $40.70 \pm 0.75$ \\
\hline Number of workers in the first brood & $10.33 \pm 1.20$ & $6.71 \pm 0.97$ & $7.60 \pm 1.01$ \\
\hline $\begin{array}{l}\text { Total syrup consumption } \\
\text { during the 11 weeks (ml) }\end{array}$ & $546.17 \pm 38.27$ & $510.14 \pm 38.42$ & $461.10 \pm 23.62$ \\
\hline $\begin{array}{l}\text { Total pollen consumption } \\
\text { during the 11 weeks (g) }\end{array}$ & $190.58 \pm 11.21$ & $180.46 \pm 17.44$ & $164.25 \pm 5.79$ \\
\hline $\begin{array}{l}\text { Total number of workers at } \\
\text { the end of the 11 weeks }\end{array}$ & $58.66 \pm 2.17$ & $55.14 \pm 1.32$ & $53.30 \pm 1.23$ \\
\hline
\end{tabular}


Proportion of queens that laid eggs and founded colonies and saleable colonies depending on the feeding regimes

\begin{tabular}{||l|c|c|c||}
\hline \multirow{2}{*}{$\begin{array}{c}\text { Queen } \\
\text { characteristics }\end{array}$} & \multicolumn{3}{|c|}{ Syrups } \\
\cline { 2 - 4 } & $\begin{array}{c}\text { HFCS-42 } \\
(\mathbf{n}=\mathbf{2 0})\end{array}$ & $\begin{array}{c}\text { SS } \\
(\mathbf{n}=\mathbf{2 0})\end{array}$ & $\begin{array}{c}\text { BFSS } \\
(\mathbf{n}=\mathbf{2 0})\end{array}$ \\
\hline Egg laying rate (\%) & 85.00 & 85.00 & 90.00 \\
\hline $\begin{array}{l}\text { Colony production } \\
\text { rate (\%) }\end{array}$ & 50.00 & 45.00 & 75.00 \\
\hline $\begin{array}{l}\text { Saleable colony } \\
\text { production rate (\%) }\end{array}$ & 30.00 & 35.00 & 50.00 \\
\hline
\end{tabular}

total syrup consumption was observed in the treatment with HFCS $(546.17 \pm 38.27 \mathrm{ml})$ and the lowest in the treatment with BFSS $(461.10 \pm 23.62 \mathrm{ml})$ but the difference was not significant (Tab. 2). Figure 1 shows the cumulative syrup consumptions of the colonies during the experimental period (11 weeks). Until the social phase (when the first workers emerge), the cumulative syrup consumption was similar for all three groups of colonies. The duration of this period lasted about 6 weeks. Cumulative syrup consumption during this period varied from 52 to $55 \mathrm{ml}$.

The highest egg laying rate, colony production rate, and saleable colony production rate $(90,75$, and $50 \%$, respectively) were found in the BFSS group (Tab. 3). However, no significant difference was found among treatments in terms of the egg laying rate, colony production rate, saleable colony production rate, and mortality rate according to the chisquare values $\left(\chi^{2}=0.29, \mathrm{P}=0.87 ; \chi^{2}=2.92\right.$, $\mathrm{P}=0.23 ; \chi^{2}=1.83, \mathrm{P}=0.40 ; \chi^{2}=2.26, \mathrm{P}=0.32$, respectively).

\section{DISCUSSION}

Bees collect nectar as their principal carbohydrate source. Chemically, nectar is a solution of sugars in water, with minor amounts of numerous other constituents. Amino acids, organic acids, proteins, lipids, anti oxidants, dextrins and minerals are some of the minor constituents (B aker and Baker, 1990). Naturally, nectars are composed of various combinations of sucrose, glucose, and fructose. It is known that balanced syrups containing similar amounts of sucrose, glucose, and fructose have been widely used in the bumble bee rearing industry. There are, however, no published data about the effects of different sugar syrups on the colony development of B. terrestris. Therefore, our results are not directly comparable with previous results. Surprisingly, there has been relatively limited scientific research done comparing different sugar syrups for the honey bee (Wykes, 1952; Barker and Lehner, 1978; Ceksteryte and Racys, 2006). We decided to compare the effects of three kinds of sugar syrups: sucrose, high fructose corn (fructose $42-45 \%$, glucose $50-54 \%$ ), and industrial bee feeding (fructose $37-40 \%$, glucose $27-30 \%$, sucrose $30-36 \%$ ) syrups because all are available commercially, and because there is a great interest in obtaining more information about the most adequate syrup diet to rear bumble bees.

In commercial rearing, one of the main criterions is how many out of 100 queens can establish colonies of saleable quality (including around 50 workers). Moreover, rapid colony initiation and successful colony production are the major criteria to reduce production costs. A proportion of queens die in the egg laying stage. Some of the remaining queens lay eggs but some do not lay eggs. Some of the reared colonies cannot be used for pollination because they contain such a small numbers of workers or produce males quite early. Food quality and quantity, queen quality, and environmental factors have an influence on the success of a colony's foundation and on the egg laying of the queens (Riberio 
et al., 1996; Velthuis and Doorn, 2006; Gurel and Gosterit, 2008b; Tasei and Aupinel, 2008). In our experiment the queens from the BFSS treatment produced approximately $15 \%$ and $20 \%$ more saleable colonies than those from the SS treatment and the HFCS treatment, respectively. Similarly, egg laying rate and colony production rate values for colonies fed on BFSS, tended to be bigger than those for colonies fed on SS and HFSC but the differences were not significant. Our observations showed that until the colonies were large enough for sale (5060 workers), the consumption of sugar syrup and pollen per one colony varied from 461 to $546 \mathrm{ml}$ and from 164 to $190 \mathrm{~g}$, respectively. This is important data for the bumble bee breeders so that they may plan year-round rearing.

\section{CONCLUSIONS}

Queens that were fed with industrial bee feeding sugar syrup (BFSS - fructose $37-40 \%$, glucose $27-30 \%$, sucrose $30-36 \%$ ) produced approximately $30 \%$ and $25 \%$ more colonies than those fed with sucrose syrup (SS - sucrose 99\%), and high fructose corn syrup (HFCS - fructose $42-45 \%$, glucose $50-54 \%$ ), respectively.

The time of emergence of the first worker, the number of workers in the first brood, and the total number of workers produced by each colony did not vary significantly between the three syrup diets.

We also observed no significant differences in total pollen consumption (which varied from 164 to $190 \mathrm{~g}$ ) and total syrup consumption (which varied from 461 to $546 \mathrm{ml}$ ) between the treatments.

\section{ACKNOWLEDGEMENTS}

This study was financed by The Scientific and Technical Research Council of Turkey (TUBITAK), grant number: 109O342, and the Scientific Research Projects Unit of Akdeniz University (BAPYB, No: 2010.02.0121.042). We also acknowledge the material support provided by the Konya Sugar Company.

\section{REFERENCES}

Baker H. G., Baker I. (1990) - The predictive value of nectar chemistry to the recognition of pollinator types. Isr. J. Bot., 39: 157-166.

Barker R. J., Lehner Y. (1978) - Laboratory comparison of high fructose corn syrup, grape syrup, honey, and sucrose syrup as maintenance food for caged honey bees. Apidologie, 9: 111-116.

Beekman M., Van Stratum P. (2000) Does the diapause experience of bumblebee queens Bombus terrestris affect colony characteristics? Ecol. Entomol., 25: 1-6.

Ceksteryte V., Racys J. (2006) - The quality of syrups used for bee feeding before winter and their suitability for bee wintering. J. Apic. Sci., 50: 5-14.

Genissel A., Aupinel P., Bressac C., Tasei J. N., Chevrier C. (2002) - Influence of pollen origin on performance of Bombus terrestris micro-colonies. Entomol. Exp. Appl., 104: 329-336.

Gurel F., Gosterit A. (2008a) - Effects of different stimulation methods on colony initiation and development of Bombus terrestris L. (Hymenoptera: Apidae) queens. Appl. Entomol. Zool., 43:113-117.

Gurel F., Gosterit A. (2008b) - The effects of feeding pollen cake containing royal jelly on Bombus terrestris L. (Hymenoptera: Apidae) colony development. Turk. J. Vet. Anim. Sci., 32: 1-5.

Hughes M. J. (1996) - Commercial rearing of bumble bees. In: Matheson A. (Ed.) Bumble bees for pleasure and profit. IBRA, Cardiff, UK, pp. 40-47.

Plowright R. C., Jay S. C. (1966) - Rearing bumble bee colonies in captivity. J. Apic. Res., 5: $155-165$.

Rasmont P., Regali A., Ings T. C., Lognay G., Baudart E., Marlier M., Delcarte E., Viville P., Marot C., Falmagne P., Veriiaegiie J. C., Chittka L. (2005) - Analysis of pollen and nectar of Arbutus unedo as a food source for Bombus terrestris (Hymenoptera: Apidae). J. Econ. Entomol., 98: 656-663. 
Ribeiro M. F., Duchateau M. J., Velthuis H. H. W. (1996) - Comparison of the effects of two kinds of commercially available pollen on colony development and queen production in the bumble bee Bombus terrestris L. (Hymenoptera, Apidae). Apidologie, 27: 133-144.

Tasei J. N., Aupinel P. (2008) - Nutritive value of 15 single pollens and pollen mixes tested on larvae produced by bumblebee workers (Bombus terrestris, Hymenoptera: Apidae). Apidologie, 39: 397-409.
Velthuis H. H. W., Doorn A. V. (2006) - A century of advances in bumblebee domestication and the economic and environmental aspects of its commercialization for pollination. Apidologie, 37: 421-451.

Wykes G. R. (1952) - The preferences of honeybees for solutions of various sugars which occur in nectar. J. Exp. Bio., 29: 511-519.

\title{
WPLYW PODKARMIANIA RODZIN TRZMIELA (Bombus terrestris L.) TRZEMA RODZAJAMI SYROPU NA ICH ROZWÓJ
}

\author{
Gurel F., Karsli B. A., Gosterit A \\ S t r e s z c z e n i e
}

Przetestowano wpływ podkarmiania trzema rodzajami syropów na rozwój rodzin trzmiela Bombus terrestris dalmatinus, wyprowadzonych od 60 matek. Rodziny podzielono losowo na trzy grupy i karmiono: syropem kukurydzianym o wysokiej zawartości fruktozy (HFCS - 42-45\% fruktozy, 50-54\% glukozy), syropem sacharozowym (SS - 99\% sacharozy) oraz przemysłowym syropem dla pszczół (BFSS - 37-40\% fruktozy, 27-30\% glukozy, 30-36\% sacharozy). Rodziny karmione były również takim samym świeżym pyłkiem i utrzymywane w standardowych warunkach laboratoryjnych (temperatura: $28 \pm 1{ }^{\circ} \mathrm{C}$, wilgotność względna: $60 \pm 5 \%$ ). Rodziny były karmione do woli pyłkiem oraz syropami (stosunek wody do cukru wynosił w przybliżeniu 1:1). W czasie okresowych obserwacji rodzin odnotowano parametry rozwoju każdej z nich. Zmierzono także tygodniowe spożycie syropu, całkowite spożycie syropu oraz całkowite spożycie pyłku przez każdą z rodzin. Najwyższe współczynniki: składania jaj, wyprowadzania robotnic i osiągania wielkości handlowej (odpowiednio 90, 75 i 50\%) stwierdzono w grupie rodzin podkarmianych BFSS. Jednak biorąc pod uwagę zbadane parametry rodziny nie stwierdzono istotnych różnic między grupami karmionymi różnymi rodzajami syropów. Do momentu osiągnięcia wielkości handlowej (50-60 robotnic) spożycie syropu na rodzinę wahało się od 461 do $546 \mathrm{ml}$, a pyłku - od 164 do $190 \mathrm{~g}$.

Słowa kluczowe: trzmiel, Bombus terrestris, podkarmianie, syrop, rozwój rodziny. 